\title{
Performance Evaluation of Selected Packaging Materials on the Chemical Compositions and Consumer Acceptability of Roasted Groundnut Seeds Stored at Ambient Temperature
}

\author{
Florence A. Bello ${ }^{1}$, Uwakmfon E. Etim ${ }^{1}$ and Titus U. Nwabueze ${ }^{2}$ \\ ${ }^{1}$ Department of Food Science and Technology, University of Uyo, Uyo, Nigeria \\ ${ }^{2}$ Department of Food Science and Technology, Michael Okpara University of Agric., Umudike, Nigeria \\ Email: florenceabello@uniuyo.edu.ng
}

\begin{abstract}
This study reports the performance of packaging materials used in the storage of roasted groundnuts under ambient temperature $\left(28 \pm 2{ }^{\circ} \mathrm{C}\right)$ in a $3 \times 4$ factorial experimental design. The groundnut samples, divided into four portions, were roasted with gari as heat medium. The groundnuts were separated from the medium and allowed to cool before packaging. The roasted groundnut seeds were analyzed as fresh (control), packaged in glass bottle, plastic bottle and low density polyethylene (LDPE) for four weeks. Proximate composition, anti-nutritional properties and sensory evaluation were carried out at weekly intervals. The result showed that packaging materials and storage duration had significant $(\mathrm{p}<0.05)$ effect on moisture, crude protein, ash and carbohydrate contents of the roasted groundnuts while significant $(\mathrm{p}>0.05)$ change was not observed in crude fat and fibre contents. The highest moisture content was observed in roasted groundnut packaged in LDPE while the glass bottle had the least value. Roasting gradually reduced the selected anti-nutrients (oxalate, phytate, tannin and $\mathrm{HCN}$ ) of the raw groundnut seeds in conjunction with the packaging materials and storage duration. Sensory acceptability scores for roasted groundnuts stored in glass bottle were the highest when compared with other packaging materials. The glass bottle may be recommended as a choice packaging material for commercial storage of roasted groundnuts for all-round availability and utilization.
\end{abstract}

Keywords: Groundnuts, roasting, packaging, storage, nutritional composition.

\section{Introduction}

Legumes have been an essential part of the human diet for centuries, with a major role in global food security, environmental challenges, and healthy diets [1]. Groundnut also known as peanut or earthnut is an edible seed of legume Arachis hypogeae Linn. The botanical name Arachis hypogaea Linn is derived from two Greek words, Arachis means 'a legume' and hypogaea means 'below ground' referring to the formation of pods in the soil $[2,3]$. Nigeria produces over 1.55 million metric tonnes of groundnut annually and is presently the first largest producers in Africa and the third largest in the world [4]. Groundnut seeds make an important contribution to the diet in many countries. It is a good source of proteins, lipids, and fatty acids for human nutrition [5,6]. It is an important item in several confectionery products and in supplementary feeding programmes such as in weaning food formulations in combination with cereals in many developing countries such as Nigeria.

Majority of the food from plant source contain some amount of anti-nutrients in them and are known to reduce the bioavailability of nutrients in the body. Like other legumes, groundnut contains antinutrients like tannins, phytate, oxalate and alkaloids which limit maximum utilization of the nutrient present in the groundnut [7]. The presence of these anti-nutrients might not be an impediment, as proper processing methods can make them edible for a safe use [8]. Roasting, which is a common local processing method in Africa, improves colour, extends shelf life, enhances flavor and reduces the antinutrient factors of legumes $[9,10]$.

Packaging is an integral part of any food industry as it affects the quality and stability of a food product. Packaging helps in protecting foods against contamination and adverse environmental conditions that can initiate deterioration of such foods [11]. Groundnuts are highly perishable in all forms and are vulnerable to moulds that produce aflatoxins. The introduction of proper packaging 
materials for packaging roasted groundnut will aid in curbing the perishability of roasted groundnut and also enhance its shelf life [12]. This will not only protect roasted groundnut from moisture loss or gain, aroma loss or gain, oxidation by oxygen, deterioration during storage and microbial attack, but also promotes sales and a point of attractive appeal to consumers. Therefore, the objective of the study was to evaluate the performance of different packaging materials on proximate composition, anti-nutrients components and sensory properties of roasted groundnut at ambient temperature storage.

\section{Materials and Methods}

\subsection{Experimental Design}

A 3x4 factorial experiment using completely randomized design was conducted (Table 1). The two factors were packaging materials and storage duration at three and four level, respectively.

Table 1. Treatment combinations

\begin{tabular}{lllll}
\hline & \multicolumn{3}{l}{ Factor 2 (Storage duration) } \\
\cline { 2 - 5 } Factor 1 (Packaging materials) & $\mathrm{W}_{1}$ & $\mathrm{~W}_{2}$ & $\mathrm{~W}_{3}$ & $\mathrm{~W}_{4}$ \\
\hline $\mathrm{G}$ & $\mathrm{GW}_{1}$ & $\mathrm{GW}_{2}$ & $\mathrm{GW}_{3}$ & $\mathrm{GW}_{4}$ \\
$\mathrm{P}$ & $\mathrm{PW}_{1}$ & $\mathrm{PW}_{2}$ & $\mathrm{PW}_{3}$ & $\mathrm{PW}_{4}$ \\
$\mathrm{~L}$ & $\mathrm{LW}_{1}$ & $\mathrm{LW}_{2}$ & $\mathrm{LW}_{3}$ & $\mathrm{LW}_{4}$ \\
RG (Raw groundnut) & & & \\
FRG (Freshly roasted groundnut) & Control & & \\
\hline
\end{tabular}

$\mathrm{G}=$ Glass, $\mathrm{P}=$ Plastic, $\mathrm{L}=$ Low Density Polyethylene (LDPE), $\mathrm{W}_{1}=$ Week $1, \mathrm{~W}_{2}=$ Week

$2, \mathrm{~W}_{3}=$ Week 3 and $\mathrm{W}_{4}=$ Week 4 .

\subsection{Sample Collection}

Raw groundnut was purchased at Itam main market Akwa Ibom State, Nigeria. The equipment and reagents used were those from Departments of Food Science and Technology Laboratory, University of Uyo, Uyo, Akwa Ibom State.

\subsection{Sample Processing}

The shelled groundnut seeds were divided into four equal portions. The first portion was cleaned and analysed as raw sample while the remaining portions were washed with distilled water to remove impurities, salted and sun-dried in a tray for $20 \mathrm{~min}$. The groundnut seeds were roasted at $150{ }^{\circ} \mathrm{C}$ for 20 min in a hot pan containing hot gari as heat medium with intermittent stirring. The groundnut seeds were separated from gari and allowed to cool and peel was removed. Part of the roasted groundnut was analysed immediately while the remaining parts were packaged with three different packaging materials (glass bottle, plastic bottle and Low Density Polyethylene (LDPE). The packaged roasted groundnut were kept at ambient temperature $\left(28 \pm 2{ }^{\circ} \mathrm{C}\right)$ and examined at one week interval for four weeks.

\subsection{Determination of Proximate Composition}

The groundnut samples were analyzed for their moisture, crude protein, crude fat, ash and crude fibre contents according to the method described by [13]. Carbohydrate was determined by difference i.e. $\%$ carbohydrate $=100-(\%$ moisture $+\%$ crude protein $+\%$ crude fat $+\%$ ash $+\%$ crude fibre $)$.

\subsection{Determination of Anti-nutrients}

Four (4) selected anti-nutritional components were determined, these include: oxalate, phytate, tannin and hydrogen cyanide (HCN). Oxalate content of the samples was determined using AOAC (2005) method. Phytate was determined using the method of [14]. Tannin content was determined using the 
method described by [15] while the method used for the determination of HCN was alkaline picrate method of [16].

\subsection{Sensory Evaluation}

Groundnut samples stored in three (3) different packaging material and freshly roasted groundnut were evaluated weekly for aroma, colour, taste and general acceptance by a panel of 20 judges on a 9 point hedonic scale ( $9=$ extremely disliked, $1=$ extremely liked) as described by [17].

\section{7 $\quad$ Statistical Analysis}

The data obtained were subjected to Analysis of Variance (ANOVA) using SPSS statistical software version 21.0. Means of triplicate data were separated using Duncan New Multiple Range Test and a level of $\mathrm{p}<0.05$ was used to indicate significant differences among the mean data.

\section{Results and Discussion}

The proximate composition of raw, freshly roasted and packaged roasted groundnut stored at ambient temperature is presented in Table 2. The moisture, crude protein, ash and carbohydrate contents of the roasted groundnut seeds were significantly $(\mathrm{p}<0.05)$ affected by the packaging materials and storage duration except crude fat and fibre contents. The highest moisture content (8.17\%) was observed in roasted groundnut packaged in LDPE at week 4 of storage $\left(\mathrm{LW}_{4}\right)$. The result is in agreement with the report of [12] who studied the effect of relative humidity, thickness of polythene packaging material and duration of storage on shelf-life of roasted cashew nuts. It was observed by these researchers that moisture content of all the samples increased with increase in duration of storage at constant polythene thickness level and also, as the thickness of the polythene packaging material increased, the amount of moisture absorbed over time (in days) decreases. Glass bottle had the lowest moisture content for roasted groundnut when compared with raw (15.31\%) and freshly roasted (5.01\%). This implies that roasted groundnut has high shelf life and storage capacity than the raw and freshly roasted. The storage in glass bottle posed less danger of spoilage in terms of constituting a barrier against moisture since moisture poses a great postharvest threat to hygroscopic food commodities like roasted groundnuts. This finding agrees with the result obtained by [18] who studied the shelf-life of infrared dry-roasted almonds. The crude protein content of the samples at storage ranged from $21.75-28.84 \%$ for LDPE at week 4 $\left(\mathrm{LW}_{4}\right)$ and glass bottle at week $1\left(\mathrm{GW}_{1}\right)$, respectively, while the raw and roasted samples were $28.85 \%$ and $26.84 \%$, respectively. Significant $(\mathrm{p}<0.05)$ reduction in crude protein content was observed after roasting and also in all the packaging materials as the storage duration progressed. Similar observation was reported for roasted benniseed and Bambara groundnut [19]. Packaging materials and storage duration had no significant $(\mathrm{p}>0.05)$ effect on the crude fat content of the roasted groundnut. It ranged from $39.11 \%$ for LDPE at week 4 to $44.85 \%$ for glass bottle at week 2 . This result agrees with the finding of [20]. Ash content of samples at storage ranged from 2.26-3.76\%. The highest value was found in glass bottle while the least value was recorded for LDPE. These values were lower than the value $(3.87 \%)$ recorded for freshly roasted groundnut. No significant $(\mathrm{p}>0.05)$ difference was observed in the crude fibre content of all the groundnut samples. It ranged from 2.00-2.46\% for plastic bottle at week 4 and 1, respectively. Significant $(\mathrm{p}<0.05)$ increase in carbohydrate content was noticed in all the packaging materials during storage. Carbohydrate content of roasted groundnut samples in storage ranged from $14.87-26.50 \%$. The highest value was found in roasted groundnut packaged with LDPE. It was also observed that glass bottle gave the least values but still higher than the freshly roasted (16.86\%) and raw groundnut (5.21\%). The result disagrees with the report of [21] who reported decreased values in seeds of mustard, linseed and groundnut after roasting. 
Table 2. Interaction effect between packaging materials and storage duration on proximate composition (\%) of roasted groundnut seeds

\begin{tabular}{|c|c|c|c|c|c|c|}
\hline Sample code & Moisture & Crude protein & Crude fat & Ash & Crude fibre & Carbohydrate \\
\hline FRG & $5.01 \pm 0.24^{\mathrm{f}}$ & $26.84 \pm 0.89^{\mathrm{ab}}$ & $44.92 \pm 2.21^{\mathrm{a}}$ & $3.87 \pm 0.14^{\mathrm{a}}$ & $2.50 \pm 0.28^{\mathrm{a}}$ & $16.86 \pm 0.33^{\mathrm{f}}$ \\
\hline $\mathrm{GW}_{1}$ & $5.04 \pm 0.24^{\mathrm{f}}$ & $28.84 \pm 1.07^{\mathrm{a}}$ & $44.51 \pm 1.89^{\mathrm{b}}$ & $3.76 \pm 0.23^{\mathrm{a}}$ & $2.45 \pm 0.38^{\mathrm{a}}$ & $15.40 \pm 0.69^{\mathrm{f}}$ \\
\hline $\mathrm{GW}_{2}$ & $5.04 \pm 0.08^{\mathrm{f}}$ & $27.74 \pm 0.70^{\mathrm{abc}}$ & $44.85 \pm 1.72^{\mathrm{a}}$ & $3.76 \pm 0.13^{\mathrm{a}}$ & $2.41 \pm 0.46^{\mathrm{a}}$ & $16.20 \pm 0.39^{\mathrm{e}}$ \\
\hline $\mathrm{GW}_{3}$ & $5.04 \pm 0.03^{\mathrm{f}}$ & $27.77 \pm 0.37^{\mathrm{abc}}$ & $44.07 \pm 2.97^{\mathrm{a}}$ & $3.74 \pm 0.33^{\mathrm{a}}$ & $2.40 \pm 0.39^{\mathrm{a}}$ & $16.98 \pm 0.20^{\mathrm{e}}$ \\
\hline $\mathrm{GW}_{4}$ & $5.01 \pm 0.12^{\mathrm{f}}$ & $27.72 \pm 0.78^{\mathrm{abc}}$ & $44.04 \pm 2.05^{\mathrm{a}}$ & $3.72 \pm 0.38^{\mathrm{a}}$ & $2.40 \pm 0.27^{\mathrm{a}}$ & $17.11 \pm 0.91^{\mathrm{e}}$ \\
\hline $\mathrm{PW}_{1}$ & $5.72 \pm 0.63^{\text {ef }}$ & $27.51 \pm 1.45^{\mathrm{abc}}$ & $44.52 \pm 2.93^{\mathrm{a}}$ & $3.76 \pm 0.43^{\mathrm{a}}$ & $2.46 \pm 0.48^{\mathrm{a}}$ & $16.03 \pm 2.46^{\mathrm{f}}$ \\
\hline $\mathrm{PW}_{2}$ & $5.67 \pm 0.82^{\mathrm{ef}}$ & $26.41 \pm 2.42^{\mathrm{bc}}$ & $42.17 \pm 2.90^{\mathrm{ab}}$ & $3.17 \pm .0 .16^{\mathrm{b}}$ & $2.42 \pm 0.50^{\mathrm{a}}$ & $20.16 \pm 1.38^{c}$ \\
\hline $\mathrm{PW}_{3}$ & $6.95 \pm 0.94^{\mathrm{cd}}$ & $26.07 \pm 1.91^{c}$ & $40.35 \pm 1.51^{\mathrm{ab}}$ & $2.92 \pm 0.63^{\mathrm{b}}$ & $2.40 \pm 0.18^{\mathrm{a}}$ & $21.31 \pm 1.91^{\mathrm{b}}$ \\
\hline $\mathrm{PW}_{4}$ & $7.46 \pm 0.67^{\mathrm{bc}}$ & $26.01 \pm 1.01^{\mathrm{c}}$ & $40.28 \pm 1.52^{\mathrm{ab}}$ & $2.34 \pm 0.21^{\mathrm{c}}$ & $2.00 \pm 0.11^{\mathrm{a}}$ & $21.91 \pm 1.20^{\mathrm{b}}$ \\
\hline $\mathrm{LW}_{1}$ & $6.11 \pm 0.26^{\mathrm{de}}$ & $28.31 \pm 0.81^{\mathrm{abc}}$ & $44.52 \pm 2.96^{\mathrm{a}}$ & $3.77 \pm 0.23^{\mathrm{a}}$ & $2.42 \pm 0.49^{\mathrm{a}}$ & $14.87 \pm 0.33^{\mathrm{e}}$ \\
\hline $\mathrm{LW}_{2}$ & $7.21 \pm 0.75^{\mathrm{bc}}$ & $26.04 \pm 0.96^{\mathrm{c}}$ & $42.04 \pm 1.99^{\mathrm{ab}}$ & $3.10 \pm 0.19^{b}$ & $2.33 \pm 0.32^{\mathrm{a}}$ & $19.28 \pm 0.75^{\mathrm{d}}$ \\
\hline $\mathrm{LW}_{3}$ & $8.13 \pm 0.25^{\mathrm{b}}$ & $23.15 \pm 0.68^{\mathrm{d}}$ & $39.87 \pm 1.36^{\mathrm{ab}}$ & $2.69 \pm 0.43^{\mathrm{bc}}$ & $2.25 \pm 0.25^{\mathrm{a}}$ & $23.91 \pm 0.96^{\mathrm{ab}}$ \\
\hline $\mathrm{LW}_{4}$ & $8.17 \pm 0.47^{\mathrm{b}}$ & $21.75 \pm 0.83^{\mathrm{d}}$ & $39.11 \pm 2.45^{\mathrm{ab}}$ & $2.26 \pm 0.23^{\mathrm{c}}$ & $2.21 \pm 0.25^{\mathrm{a}}$ & $26.50 \pm 1.35^{\mathrm{a}}$ \\
\hline $\mathrm{RG}$ & $15.31 \pm 1.00^{\mathrm{a}}$ & $28.85 \pm 0.31^{\mathrm{a}}$ & $44.53 \pm 2.94^{\mathrm{a}}$ & $3.70 \pm 0.10^{\mathrm{a}}$ & $2.40 \pm 0.10^{\mathrm{a}}$ & $5.21 \pm 0.90^{\mathrm{g}}$ \\
\hline $\mathrm{Mn}$ & 6.85 & 26.64 & 42.84 & 3.33 & 2.36 & 17.98 \\
\hline $\mathrm{CV}$ & 0.39 & 0.09 & 0.17 & 0.19 & 0.13 & 0.18 \\
\hline $\mathrm{p}<0.05$ & $0.000^{*}$ & $0.000 *$ & $0.515^{\mathrm{ns}}$ & $0.000 *$ & $0.947^{\mathrm{ns}}$ & $0.021^{*}$ \\
\hline
\end{tabular}

$*$ and ns represent significant at $5 \%$ and non-significant at $5 \%$ probability level, respectively. Mean values followed by the same letter in the column are not significantly different at $5 \%$ probability level. $\mathrm{GW}_{1}, \mathrm{GW}_{2}$, $\mathrm{GW}_{3}$ and $\mathrm{GW}_{4}$. Roasted groundnut stored in glass bottle for 1, 2, 3 and 4 week, respectively; $\mathrm{PW}_{1}, \mathrm{PW}_{2}, \mathrm{PW}_{3}$ and $\mathrm{PW}_{4}$. Roasted groundnut stored in plastic bottle for 1, 2, 3 and 4 week, respectively, and $\mathrm{LW}_{1}, \mathrm{LW}_{2}, \mathrm{LW}_{3}$ and $\mathrm{LW}_{4}$. Roasted groundnut stored in LDPE for 1, 2, 3 and 4 week, respectively. $\mathrm{RG}=\mathrm{Raw}$ Groundnut, $\mathrm{FRG}=$ Freshly Roasted Groundnut, $\mathrm{Mn}=$ ground mean and $\mathrm{CV}=$ Coefficient of Variation.

The selected anti-nutritional composition of raw, freshly roasted and stored groundnut is presented in Table 3. Significant $(\mathrm{p}<0.05)$ difference was observed in all the parameters analysed. Oxalate, phytate, tannin and HCN contents of the stored roasted groundnut ranged from $0.00-0.24 \mathrm{mg} / \mathrm{g}, 0.05-0.33 \mathrm{mg} / \mathrm{g}$, $0.017-0.038 \mathrm{mg} / \mathrm{g}$ and $0.000-0.010 \mathrm{mg} / \mathrm{g}$, respectively. The results showed that roasting gradually reduced the trace amounts of anti-nutrient components found in raw groundnut seeds. Both packaging materials and storage duration, however, had the same significant $(\mathrm{p}<0.05)$ reducing effect on the level of oxalate, phytate and tannin concentration in roasted groundnut. Anti-nutritional components are known to reduce the bioavailability of nutrients in the body. Oxalates affect calcium, magnesium and protein metabolism in man. They also react with calcium to form calcium oxalates which are responsible for the formation of kidney stone in human subjects [22]. Phytates are known to reduce bioavailability of minerals, impair protein digestibility caused by formation of phytic-protein complexes and hinder absorption of nutrients due to damage to the pyloric caeca region of the intestine [23]. Anti-nutritional effects of tannins include interference with the digestive processes either by binding enzymes or by binding to food components like proteins or minerals [24]. Tannins at their safe level (below 100ppm) have some health benefits as they play significant roles in the prevention of cavities, diarrhoea, tooth decay and heart diseases $[25,26]$.

The result of the sensory scores of the roasted groundnut samples is shown in Table 4. Flavour and colour are important attributes affecting the consumer preference of roasted groundnuts [27,28]. Packaging materials significantly $(\mathrm{p}<0.05)$ affect the aroma, colour, taste and general acceptability of the stored roasted groundnut. The sensory scores ranged from 4.66-8.13, 5.24-8.53, 2.50-8.65 and 4.508.47 for aroma, colour, taste and general acceptability, respectively. The highest scores were found in groundnut packaged with glass bottle at week 1 of storage while the least values were observed in LDPE at week 4 of storage. There was general decreasing trend in the scores from week 1 to 4 of storage for all the parameters evaluated by the judges. Sample stored in glass bottle was judged as the most acceptable because it showed little or no decrease in sensory qualities whereas LDPE was disliked at the end of storage due to its loss of sensory qualities like aroma and taste in comparison with the control. 
Table 3. Interaction effect between packaging materials and storage duration on anti-nutrient composition (mg/g) of roasted groundnut seeds

\begin{tabular}{lllll}
\hline Sample code & Oxalate & Phytate & Tannin & HCN \\
\hline FRG & $0.30 \pm 0.05^{\text {abc }}$ & $0.29 \pm 0.04^{\text {bcd }}$ & $0.038 \pm 0.000^{\mathrm{a}}$ & $0.000 \pm 0.001^{\mathrm{c}}$ \\
$\mathrm{GW}_{1}$ & $0.31 \pm 0.03^{\mathrm{abc}}$ & $0.33 \pm 0.02^{\mathrm{b}}$ & $0.038 \pm 0.003^{\mathrm{a}}$ & $0.001 \pm 0.001^{\mathrm{b}}$ \\
$\mathrm{GW}_{2}$ & $0.32 \pm 0.03^{\mathrm{abc}}$ & $0.32 \pm 0.02^{\mathrm{b}}$ & $0.034 \pm 0.003^{\mathrm{ab}}$ & $0.000 \pm 0.000^{\mathrm{c}}$ \\
$\mathrm{GW}_{3}$ & $0.31 \pm 0.02^{\mathrm{abc}}$ & $0.30 \pm 0.09^{\mathrm{bcd}}$ & $0.035 \pm 0.003^{\mathrm{a}}$ & $0.000 \pm 0.000^{\mathrm{c}}$ \\
$\mathrm{GW}_{4}$ & $0.29 \pm 0.01^{\mathrm{bcd}}$ & $0.28 \pm 0.01^{\mathrm{bcd}}$ & $0.034 \pm 0.004^{\mathrm{ab}}$ & $0.000 \pm 0.000^{\mathrm{c}}$ \\
$\mathrm{PW}_{1}$ & $0.33 \pm 0.02^{\mathrm{ab}}$ & $0.32 \pm 0.02^{\mathrm{b}}$ & $0.038 \pm 0.002^{\mathrm{a}}$ & $0.001 \pm 0.001^{\mathrm{b}}$ \\
$\mathrm{PW}_{2}$ & $0.31 \pm 0.01^{\mathrm{abc}}$ & $0.31 \pm 0.01^{\mathrm{bc}}$ & $0.034 \pm 0.003^{\mathrm{ab}}$ & $0.000 \pm 0.000^{\mathrm{c}}$ \\
$\mathrm{PW}_{3}$ & $0.28 \pm 0.01^{\mathrm{cde}}$ & $0.28 \pm 0.01^{\mathrm{bcd}}$ & $0.035 \pm 0.003^{\mathrm{a}}$ & $0.000 \pm 0.000^{\mathrm{c}}$ \\
$\mathrm{PW}_{4}$ & $0.25 \pm 0.03^{\mathrm{de}}$ & $0.25 \pm 0.03^{\mathrm{cd}}$ & $0.033 \pm 0.002^{\mathrm{ab}}$ & $0.000 \pm 0.000^{\mathrm{c}}$ \\
$\mathrm{LW}_{1}$ & $0.34 \pm 0.02^{\mathrm{a}}$ & $0.30 \pm 0.09^{\mathrm{bcd}}$ & $0.036 \pm 0.002^{\mathrm{a}}$ & $0.001 \pm 0.001^{\mathrm{b}}$ \\
$\mathrm{LW}_{2}$ & $0.24 \pm 0.03^{\mathrm{e}}$ & $0.24 \pm 0.02^{\mathrm{d}}$ & $0.026 \pm 0.003^{\mathrm{bc}}$ & $0.000 \pm 0.000^{\mathrm{c}}$ \\
$\mathrm{LW}_{3}$ & $0.00 \pm 0.00^{\mathrm{f}}$ & $0.11 \pm 0.01^{\mathrm{e}}$ & $0.021 \pm 0.009^{\mathrm{cd}}$ & $0.000 \pm 0.000^{\mathrm{c}}$ \\
$\mathrm{LW}_{4}$ & $0.00 \pm 0.00^{\mathrm{f}}$ & $0.05 \pm 0.02^{\mathrm{f}}$ & $0.017 \pm 0.002^{\mathrm{d}}$ & $0.000 \pm 0.000^{\mathrm{c}}$ \\
$\mathrm{RG}_{\mathrm{Mn}}$ & $0.33 \pm 0.03^{\mathrm{ab}}$ & $0.46 \pm 0.01^{\mathrm{a}}$ & $0.039 \pm 0.010^{\mathrm{a}}$ & $0.010 \pm 0.000^{\mathrm{a}}$ \\
$\mathrm{CV}$ & 0.258 & 0.274 & 0.033 & 0.001 \\
$\mathrm{p}<0.05$ & 0.44 & 0.36 & 0.23 & 2.59 \\
\hline
\end{tabular}

$*$ represent significant at $5 \%$ probability level. Mean values followed by the same letter in the column are not significantly different at $5 \%$ probability level. See the sample code in Table 2.

Table 4. Interaction effect between packaging materials and storage duration on sensory evaluation of roasted groundnut seeds

\begin{tabular}{lllll}
\hline Sample code & Aroma & Colour & Taste & General acceptability \\
\hline FRG & $8.83^{\mathrm{a}} \pm 0.15$ & $8.93^{\mathrm{a}} \pm 0.12$ & $8.87^{\mathrm{a}} \pm 0.12$ & $8.93^{\mathrm{a}} \pm 0.12$ \\
$\mathrm{GW}_{1}$ & $8.13^{\mathrm{b}} \pm 0.15$ & $8.53^{\mathrm{b}} \pm 0.11$ & $8.65^{\mathrm{a}} \pm 0.15$ & $8.47^{\mathrm{b}} \pm 0.25$ \\
$\mathrm{GW}_{2}$ & $7.65^{\mathrm{c}} \pm 0.18$ & $8.35^{\mathrm{b}} \pm 0.15$ & $8.62^{\mathrm{ab}} \pm 0.10$ & $8.35^{\mathrm{b}} \pm 0.19$ \\
$\mathrm{GW}_{3}$ & $7.37^{\mathrm{d}} \pm 0.17$ & $8.11^{\mathrm{c}} \pm 0.11$ & $8.30^{\mathrm{bc}} \pm 0.09$ & $8.23^{\mathrm{b}} \pm 0.15$ \\
$\mathrm{GW}_{4}$ & $7.15^{\mathrm{d}} \pm 0.18$ & $7.90^{\mathrm{c}} \pm 0.10$ & $8.10^{\text {cd }} \pm 0.10$ & $7.90^{\mathrm{c}} \pm 0.09$ \\
$\mathrm{PW}_{1}$ & $6.72^{\mathrm{e}} \pm 0.14$ & $8.08^{\mathrm{c}} \pm 0.76$ & $7.83^{\mathrm{de}} \pm 0.15$ & $7.68^{\text {cd }} \pm 0.13$ \\
$\mathrm{PW}_{2}$ & $6.35^{\mathrm{f}} \pm 0.09$ & $7.62^{\mathrm{d}} \pm 0.13$ & $7.55^{\mathrm{e}} \pm 0.05$ & $7.63^{\text {cd }} \pm 0.15$ \\
$\mathrm{PW}_{3}$ & $6.07^{\mathrm{g}} \pm 0.11$ & $7.22^{\mathrm{e}} \pm 0.08$ & $7.20^{\mathrm{f}} \pm 0.27$ & $7.38^{\mathrm{d}} \pm 0.18$ \\
$\mathrm{PW}_{4}$ & $5.83^{\mathrm{h}} \pm 0.06$ & $7.07^{\mathrm{e}} \pm 0.08$ & $6.36^{\mathrm{g}} \pm 0.23$ & $6.88^{\mathrm{e}} \pm 0.28$ \\
$\mathrm{LW}_{1}$ & $6.12^{\mathrm{fg}} \pm 0.07$ & $7.05^{\mathrm{e}} \pm 0.05$ & $6.55^{\mathrm{g}} \pm 0.05$ & $6.75^{\mathrm{e}} \pm 0.18$ \\
$\mathrm{LW}_{2}$ & $5.35^{\mathrm{i}} \pm 0.18$ & $6.85^{\mathrm{f}} \pm 0.13$ & $5.73^{\mathrm{h}} \pm 0.21$ & $5.41^{\mathrm{f}} \pm 0.20$ \\
$\mathrm{LW}_{3}$ & $4.90^{\mathrm{j}} \pm 0.10$ & $6.20^{\mathrm{g}} \pm 0.10$ & $4.21^{\mathrm{i}} \pm 0.12$ & $5.14^{\mathrm{f}} \pm 0.17$ \\
$\mathrm{LW}_{4}$ & $4.66^{\mathrm{k}} \pm 0.13$ & $5.24^{\mathrm{h}} \pm 0.21$ & $2.50^{\mathrm{j}} \pm 0.44$ & $4.50^{\mathrm{g}} \pm 0.30$ \\
Mn & 6.55 & 7.47 & 7.19 & 7.18 \\
CV & 0.19 & 0.13 & 0.19 & 0.19 \\
p $<0.05$ & $0.000^{*}$ & $0.000^{*}$ & $0.000^{*}$ & $0.000^{*}$ \\
\hline
\end{tabular}

$*$ represent significant at $5 \%$ probability level. Mean values followed by the same letter in the column are not significantly different at $5 \%$ probability level. See the sample code in Table 2.

\section{Conclusions}

This study showed that storage with glass bottle is proved to be the most effective packaging for roasted groundnut especially in terms of barrier against moisture since moisture poses a great postharvest threat to hygroscopic food commodities like groundnut. Taking the factors affecting the choice of a packaging 
material into consideration and the effectiveness of glass bottle throughout the period of storage, it may be recommended for commercial storage of groundnut for all-round availability and utilization.

\section{References}

1. FAO, "Pulses: Nutritious Seeds for a Sustainable Future," Rome, Italy; ISBN 978-92-109463-1, 2016.

2. V. N. Atasie, T. F. Akinhanmi, and C. C. Ojiodu, "Proximate analysis and physico-chemical properties of groundnut (Arachis hypogaea L.)," Pakistan Journal of Nutrition, vol. 8, no. 2, pp. 194-197, 2009.

3. D. T. Bindhya, and A. Kochhar, "Peanut processing and its potential food applications," International Journal of Science and Research, vol. 4, no. 6, pp. 2701-2706, 2013.

4. Q. Wang, "Peanut processing characteristics and quality evaluation," Springer Nature Singapore Pte Ltd., pp. 2-13, 2018.

5. M. E. Carrin, and A. A. Carelli, "Peanut oil: Compositional data," European Journal of Lipid Science and Technology, no. 112, pp. 697-707, 2010.

6. M. K. Meena, M. B. Chetti, and C. M. Nawalagatti, "Influence of different packaging materials and storage conditions on the seed quality parameters of groundnut (Arachis hypogaea L.)," International Journal of Pure and Applied Bioscience, vol. 5, no. 1, pp. 933-941, 2017.

7. J. Ejigui, L. Savoie, J. Marin, and T. Desrosiers, "Influence of traditional processing methods on the nutritional composition and antinutritional factors of red peanuts (Arachis hypogea) and small red kidney beans (Phaseolus vulgaris)," Journal of Biological Sciences, vol. 5, no. 5, pp. 597-605, 2005.

8. R. Bhat, and A. A. Karim, "Exploring the nutritional potential of wild and underutilized legumes," Comprehensive Reviews in Food Science and Food Safety, vol. 8, pp. 305-331, 2009.

9. S. Sena, K. Sinan, and U. Suat, "Determination of optimum hazelnut roasting conditions," International Journal of Food Science and Technology, no. 36, pp. 271-281, 2001.

10. S. Kavitha, and R. Parimalavalli, "Effect of processing methods on proximate composition of cereal and legume flours. Journal of Human Nutrition and Food Science, vol. 2, no. 4, pp. 1051, 2014.

11. I. A. Kukoyi, O. A. Osukoya, and S. Osho, "Effect of packaging materials and storage conditions on the physicochemical compositions of groundnut oil in Nigeria," International Journal of Advanced Research in Biological Sciences, vol. 1, no. 8, pp. 184-191, 2014.

12. S. V. Irtwange, and A. O. Oshodi, "Shelf-life of roasted cashew nuts as affected by relative humidity, thickness of polythene packaging material and duration of storage," Research Journal of Applied Sciences, Engineering and Technology, vol. 1, no. 3, pp. 149-153, 2009.

13. A.O.A.C. Official methods of analysis. "Association of Official Analytical Chemist," Washington, D. C. USA, 2005.

14. E. L. Wheeler, and R. E. Ferrel, "Phytic acid determination in wheat and wheat fractions," Cereal Chem., no. 4, pp. 312-320, 1971.

15. A. Sofowora, "Medicinal plants and traditional medicine in Africa," John Wiley and Sons, Ltd, Ife, Nigeria, pp. 55-201, 1993.

16. G. I Onwuka, "Food Analysis and Instrumentation (Theory and Practiced)," $1^{\text {st }}$ Edn. Naphthali Prints, Surulere, Lagos-Nigeria, pp. 140-160 ISBN: 978047686, 2005.

17. M. O. Iwe, "Some sensory methods and data analysis," Handbook of sensory methods and analysis, 2nd Edition, Rojoint Communication Services Ltd, Enugu State, Nigeria, pp. 43-85, 2010.

18. J. Yang, Z. Pan, G. Takeoka, B. Mackey, G. Bingo, M.T. Brand..., "Shelf-life of infrared dry-roasted almonds," Food Chemistry, no. 138, pp. 671-678, 2013.

19. A. A. Yusuf, H. Ayedun, and L. O. Sanni, "Chemical composition and functional properties of raw and roasted Nigerian benniseed (Sesamum indicum) and Bambara groundnut (Vigna subterranean)," Food Chemistry, no. 111, pp. 277-282, 2008.

20. O. A. Adeiye, S. O. Gbadamosi, and A. K. Taiwo, "Effects of some processing factors on the characteristics of stored groundnut milk extract," African Journal of Food Science, vol. 7, no. 6, pp. 134-142, 2013.

21. A. Chauhan, V. Khanna, and P. Gupta, "Effects of roasting on physic-chemical properties and fatty acid concentration of different edible oil-seeds," Research Journal of Chemical Sciences, vol. 8, no. 5, pp. 19-28, 2018.

22. R. Savita, P. Gagan, Y. Rajesh, and M. K. Deen, "Screening of pigeon pea (Cajanus cajan) seeds for study of their flavonoids, total phenolic content and antioxidant properties," International Journal of Pharmaceutical Sciences Review and Research, no. 28, pp. 90-94, 2014. 
23. G. Francis, H. P. S. Makkar, and K. Becker, "Antinutritional factors present in plant-derived alternate fish feed ingredients and their effects in fish," Aquaculture, vol. 199, no. 3-4, pp. 197-227, 2001.

24. R. G. Elkin, J. C. Rogler, and T.W. Sullivan, "Comparative effects of dietary tannins in ducks, chicks, and rats," Poultry science, vol. 69, no. 10, pp. 1685-1693, 1990.

25. C. O. Oraka, and J. I. Okoye, "Effect of heat processing treatments on the nutrient and anti-nutrient contents of lima bean (Phaseolus lunatus) flour," International Journal of Food Science and Nutrition, no. 2, pp. 13-17, 2017.

26. J. I. Okoye, and G. I. Ene, "Effects of Processing on the Nutrient and Anti-Nutrient Contents of Tiger Nut (Cyperus Esculentus Lativum)," Journal of Food Technology and Food Chemistry, no. 1, pp. 101, 2018.

27. C. Lee, and A. Resurreccion, "Predicting sensory attribute intensities and consumer acceptance of stored roasted peanuts using instrumental measurements," Journal of Food Quality, vol. 29, no. 4, pp. 319-338, 2006.

28. K. McDaniel, B. White, L. Dean, T. Sanders, and J. Davis, "Compositional and mechanical properties of peanuts roasted to equivalent colours using different time/temperature combinations," Journal of Food Science, vol. 77, no. 12, pp. C1293-C1299, 2012. 